\title{
What We Will Not Burn
}

\section{Jessica Reidy}

jessica.s.reidy@gmail.com

Jessica Reidy is a writer of mixed-Sinti heritage. Her poetry, fiction, and non-fiction have appeared in Narrative Magazine as Short Story of the Week, Prairie Schooner, Kenyon Review Online, and other publications. She is the winner of the Penelope Nivens Award for Creative Nonfiction and the Glenna Luschei Prize. She is the co-host of Romanistan alongside Paulina Verminski, a podcast celebrating Roma, roots, and rebels. She is an educator, activist, artist, trauma-informed yoga teacher, and fine arts model. She also works her family trades, dancing, and healing, including herbalism, bodywork, and card, palm, and tea leaf reading.

\section{Critical}

Romani Studies 
I never really know if I'm behaving myself.

I sit amidst the long ruffles of tissue paper that litter my grandmother's trailer as she unwraps another thing and offers it to me. I pretend she does this just because I'm moving to take that job I'm not sure I want. It's not because she's old and making sure I get what I want before she dies, before the rest of the family swoops in, because I'm her favorite, and I'm leaving Arizona.

"Great Uncle Raphael's knife?" she asks, and tilts her head. "Bone handle, silver blade. Very sharp."

"Absolutely."

She weighs it in her palm before wrapping it up again and placing it in my box.

"It's good to keep the history," she says.

"I thought Sinti and Roma are supposed to burn a dead person's possessions," I say before really thinking about how it sounds, like I'm teaching her. I cringe hearing myself but she doesn't take it that way.

"Everything changed for our family after the war."

After the war means after the Nazis, after our river Gypsies stopped going up and down the Danube and went into camps instead, after she ran away with an American soldier when she didn't speak a word of English so she didn't notice he was schizophrenic. That man tortured the family at gunpoint like some fathers play catch with their sons, and it'd be a lie to say we didn't sigh, relieved when he slipped his favorite rifle in his mouth. When we cremated him, no one wanted those ashes, the boys still bruised, the girls still shaking from everything he slipped to us in the dark. We were all still burning from the bomb in his chest, and my grandmother from those charred memories before: playmates, cousins, neighbors all gone up in Germany's smokestack, devoured by a demon no one wanted to name. After all those burning bodies, she means, how could you set one more thing alight?

Everything changed after the war, she says to me, and I know what she means. Everything changes after violence.

"Is it because I have dirty blood?" I had asked her after school one blazing day in first grade. I was covered in little congealed cuts, and red dust from the long walk home masked my face. Some kids had invited me to play with them behind the cafeteria. "Come over here, Coco. Want to see something?" and then pelted my face with rocks

"This isn't your fault," my grandmother told me when I got home from school, not smoothing my hair, not hugging my shoulder, but looking at me solemnly with strong, sweet tea between us, piping hot.

I knew the kids threw rocks because they knew we were Gypsies, and the fact that we didn't go to church didn't help, but I was afraid they threw them because they could scent that I was dirty. My blood was mixed so I could not even be pure Sinti, and I thought of that when my mother mentioned her own mixed blood with shame. The worst of all my fears was that they could smell my dead grandfather's fingers on me. He was the demon that none of us knew how to fight, and though he died the season before I started school, I still dreamed of him every night. His ghost lingered in the mourning-white halls at school, the halls that shimmered and whispered, bad girl, bad girl as I walked to my classroom where my teacher waited, sure to accuse me of giving the evil eye.

I whispered to my grandmother, "I just can't follow all the rules. Not even if I tried. I'm too dirty."

"Girl, if we followed all the rules we'd be dead," she said. "My blood isn't dirty and neither is yours. We wash in running water. We eat bitter bread and cleanse our souls. We do the important things. Something bad happened to you just because bad things happen to people. The wind doesn't recognize whose wagon it blows over. And those kids don't know shit." 
And, full-grown and planning my life elsewhere, I want to ask her if I'm bad again, even though the war was years ago, and she's been a lucky widow living on her own. Even though she thinks that some rules are just stupid. Who can argue with an elder? Especially her, with her clear spooky eyes that know death is the beautiful woman who comes for us all, and could probably point her out in a crowd, sure and calm as a pot of tea. You have to scald the pot first, I remember her telling me when I was young and learning the family trades, everything from sewing to fortune-telling. It sterilizes the pot and makes a better-tasting tea and blesses the vessel for reading the leaves. I can't scald my vessel-I can't wash-out that feeling of knowing what I'm supposed to do and being afraid to do it. Take the job and learn to market a line, maybe my own line, of clothes? Stay here and sew up this town's drooping seams? I wonder if I wear my hair in braids and sew coins into my skirts that suddenly the world will make sense. But my grandmother's dresser has pictures of our ancestors like this, and if anything, it cut their world short. I look at my palms and trace the little rivers running over the sides.

"Don't read your own palm. No good comes of it," she says, slapping my hand to my side. The slap is surprisingly hard coming from an old woman.

"I don't know if I want this job," I say to her. "I don’t know if I'll be happy in L.A."

"Let me give you some advice. There's nothing for you here. What are you going to do in the desert? Go, take the job, and be happy."

I don't want to leave, but I can't tell that to a woman who left her family 50 years ago for an uncertain chance at something on the arm of a loose-cannon stranger. Gypsies are supposed to move together, I want to tell her. We run from violence or for opportunity, but in a band, like some rambling half-myth. Here my family stays, and I'm supposed to go.

"You're supposed to go places," she says, like she's listening to my thoughts. But when I think about it, that's just something she's always said. She may as well have said, "You're supposed to pick hyssop when the moon is fat." Which, of course, I do. I pick it out of the terracotta pots in my parents' house. It promises safe travel.

"Do you want this teapot?" she asks me now. "Don't you have anything to make tea in?"

I want to tell her I do, which is a lie, so she will think I make tea every week in my apartment, and read all my friends' tea leaves for practice, and for closeness, as she says. She can't know that I microwave water in a mug for three minutes, but it's a sin to lie to your Sinti grandmother, and she says it's a sin to lie to another Gypsy at all. Though that might just be something she jokes, because Devel knows all people everywhere lie to ourselves and the world at large just to make it through one more day.

And anyway, I know for a fact she doesn't believe in sin.

"Can I have it?" I ask. "I like this teapot better than the one I have now."

She hands it to me and is quiet for a moment. I think she knows I lied. My chest balloons with explanations but nothing comes out. I can't even exhale. She twists her loose hair back into a knot, all grizzled like steel wool, and asks me, "Do you still have Great-Grandmother Mathilde's thimble?"

"Of course," I say, reaching over to my purse and digging out the tiny, slightly warped thing. It sits flat on my palm, and I push it under her face, and wait for her approval.

"You'll be fine," she says, flaring her nostrils as she exhales, certain and forceful like a horse. I think of the wild white horses she told me about as a child. They live in the South of France, she said. Marvelous creatures. Some stories I heard said they were women in mourning. I think they were women broken loose.

"When you get there," she said, "I want you to keep going. Don't linger for nostalgia's sake. Nostalgia is just for drugging women dumb." 
My grandmother never got to see those horses-it wasn't safe for her to travel during the war, lest she and her family be caught by the Nazis like so many other Roma and Sinti, and the boat she took to America with her crazy soldier did not skirt horse territory in the South of France. I saw plenty of a wide, sick ocean though, she assured me, but that wasn't quite enough for her. That day I came home as a child, bloody from rocks, we drank our tea and I told her she might go on a trip someday, a big trip like she always wanted, though I was unsure whether I saw or wished this from the leaves. She flared her nostrils then too, revealing I'd hit a mark, and confessed: I always wished to see those horses, moon-colored, pale and strong, with the salt marshes sucking at their hooves as they gallop through and keep going. 